\title{
Effects of different coagulant enzymes used on quality of traditional Örgü cheese (Braided cheese)
}

doi: $10.15567 /$ mljekarstvo.2015.0108

\begin{abstract}
Mehmet Çelebi ${ }^{1}$, Bedia Şimşek²*
${ }^{1}$ A. Menderes University, Faculty of Agriculture, Department of Dairy Technology-Aydın, Turkey ${ }^{2} \mathrm{~S}$. Demirel University, Engineering Faculty, Department of Food Engineering- Isparta, Turkey

Received - Prispjelo: 12.04.2014. Accepted - Prihvaćeno: 16.01.2015.
\end{abstract}

\begin{abstract}
In this study, Örgü cheese has been produced by using different coagulating enzymes (calf rennet, microbial enzymes, recombinant chymosin). The effects of different coagulating enzymes which are used on the characteristic of mineral material and cheese has been observed during 90 days ripening time. Mineral material contents of Örgü cheese have been determined with ICP-OES (inductively coupled plasma optical emission spectroscopy). Proteolysis levels of cheese have been observed with chemical analysis and help of SDS-PAGE (sodium dodecyl sulfate polyacrylamide gel electrophoresis). The determined difference between analysis results, titratable acidity, total nitrogen, water soluble nitrogen, ripening index, total solid, fat, fat in total solid, salt, salt in total solid, ash, texture, mineral material $(\mathrm{Ca}, \mathrm{Fe}, \mathrm{Cu}, \mathrm{Al}, \mathrm{Mg}, \mathrm{Mn})$ of Örgü cheese's analysis result haven't been regarded as significant statistically. Each of enzymes which are used effects similarly on $\alpha$-casein and $\beta$-casein during the ripening time and each of the ratios which are gained have been closely determined.
\end{abstract}

Key words: Örgü Cheese, coagulating enzymes, mineral material, microstructure

\section{Introduction}

Örgü (Braided) cheese is a semi hard traditional cheese which contains high level of fat, its curd is scalded, and ripened in brine after knitting. In the production period, a fresh raw milk is filtered using cheesecloth, coagulated with rennet and cutted like small cubes. After whey draining curd is fermented until acidity as applicable to knitting in ambient temperature. In optimum acidity, curd is sliced, is scalded in hot brine $\left(72{ }^{\circ} \mathrm{C}\right.$; $\% 5$ salt $)$ and is shaped by knitting. Cheeses are consumed fresh or after ripening in brine (Figure 1) (Çelik and Türkoğlu, 2007; Hayaloğlu et al., 2008).

The main process during cheese production is coagulation of milk ( $\mathrm{Er}$ and Sarımehmetoglu, 2009). Milk coagulant enzymes are gained from animal products, especially calf rennet. Except with animal rennet, milk coagulation is possible to achieve with the proteolytic enzymes which are gained from various sources. These can be coagulating enzymes which are gained from different animal species, microbial proteases which are gained from some plants (Tejada et al., 2008; Ahmed et al., 2009). Microbial based coagulators are gained from Mucor pusillus, Rhizomucor miehei, Rhizomucor pusillus sp. lindt, Aspergillus oryzae, Mucor miehei and Endothia parasitica (Shieh et al., 2009). Recombinant chymosine is the first enzyme which is gained by using recombinant DNA technology with genetic modification, it is transferred to Kluyveromyces lactis and Aspergillus spp. (Henriksen et al., 1999).

It has been thought that the use of different enzymes will influence on the chemical, physical qualities and the yield of cheese (Alichanidis et al., 1984; Ustunol and Hicks, 1990).

In our study, calf rennet, microbial enzyme and recombinant chymosine have been used in the production of Örgü cheese from cow milk. Within 


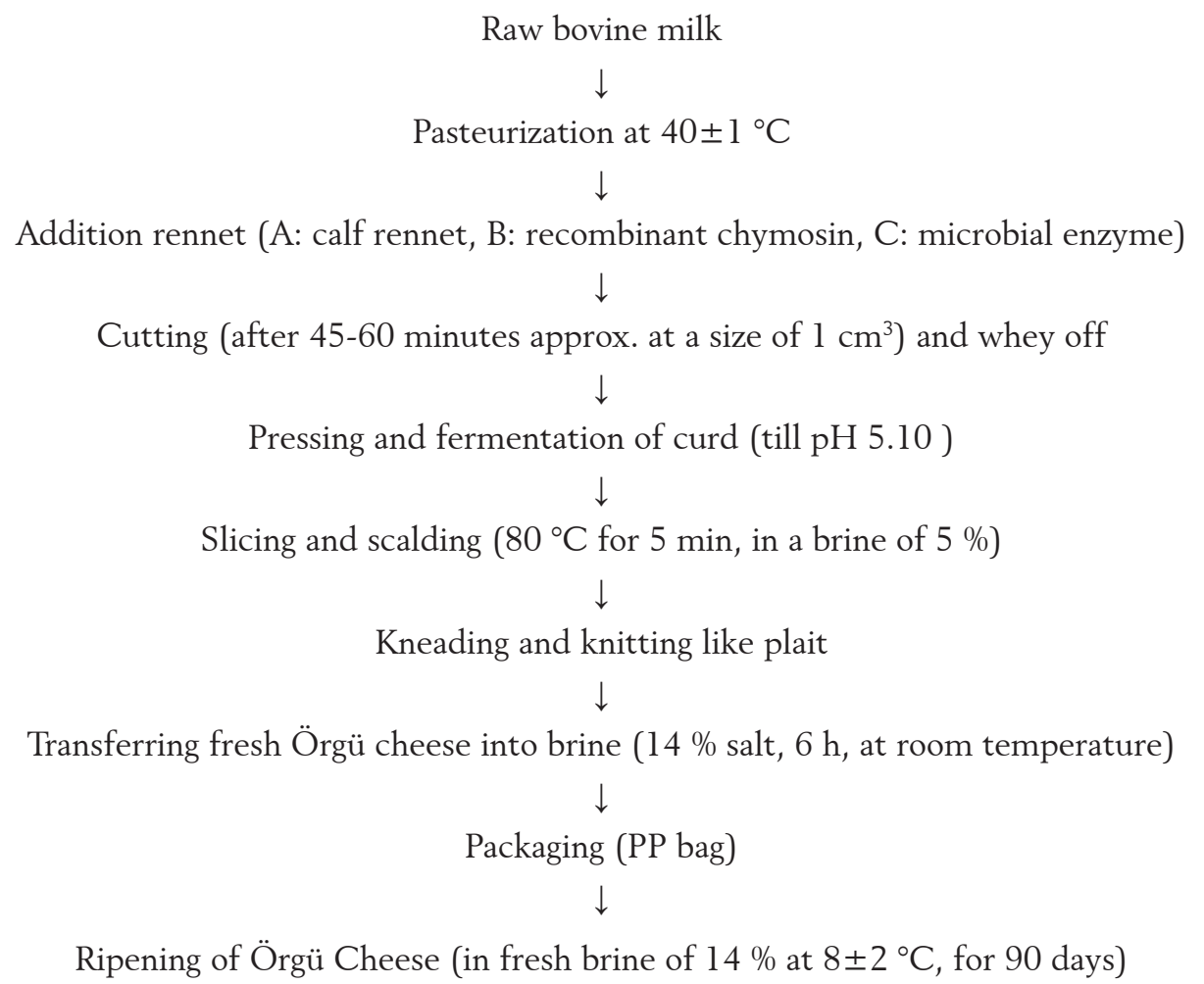

Figure 1. Schematic diagram of the manufacture of experimental Örgü Cheese

study, changes which occur depending on the usage of different enzyme during the three months storage time. It has been tried to determine the changes which occur depending on the usage of different enzyme during the three months storage time with the help of physical, chemical and biochemical analyses.

\section{Material and methods}

\section{Materials}

Raw cow's milk was supplied from Breeding Cattle Breeder Association Isparta, Turkey. In the production of cheese calf rennet (A) (Renna, \% 100 natural calf omasum, Mayasan, Istanbul, Turkey), recombinant chymosine (B) (Renmax 600 L, \% 100 Chymosine, Aspergillus niger spp. awamori with the gene technology, Mayasan, Istanbul, Turkey) and microbial enzyme (C) (Mayasan, Rhizomucor miehei protease, Mayasan Istanbul, Turkey) have been used.

\section{Methods}

\section{Cheese manufacture and sampling}

In this study, Örgü cheeses were produced using three different coagulants (calf rennet, recombinant chymosine and microbial enzyme). They were produced in triplicate and therefore three trials were done. A simplified flow chart for the production of Örgü cheese made from raw milk (RMC) is shown in Figure 1. The experimental cheese from raw milk was produced in Suleyman Demirel University Engineering Faculty, Department of Food Engineering Research and Practice Lab - Isparta, Turkey. After production, the cheese samples were transferred into jars, filled with fresh brine $(1 / 1: \mathrm{w} / \mathrm{w})$ containing $14 \%$ salt, and ripened for 90 days at $8 \pm 2{ }^{\circ} \mathrm{C}$. Cheese samples were then analyzed on the $1^{\text {st }}, 30^{\text {th }}$, $60^{\text {th }}$ and $90^{\text {th }}$ days of ripening for physical, chemical and biochemical properties.

\section{Chemical analysis}

The titratable acidity (TA, as lactic acid \%, acidity of milk- AOAC Official Method 947.05), total 
solid (TS \%, AOAC Official Method 990.20) was determined as outlined by AOAC methods (2000a, b). Fat (\%) and ash (\%) of the raw milk was determined using the method of James (1999). pH values were measured using a ph meter (wtw-ph-3110). Percentage of $\mathrm{NaCI}$, ash and fat of cheese was determined using the method of James (1999). $\mathrm{NaCl}$ content was expressed as salt concentration. Moisture contents of cheese were determined by AOAC (2000c) methods (Official Method 926.08). Total nitrogen (TN) and water-soluble nitrogen (WSN) levels were determined according to the method of Grippon et al. (1975). Protein content was calculated by multiplication of TN content with 6.38. Ripening index of Örgü cheese samples were calculated using following equation:

$$
\text { Ripening index }(\%)=(\mathrm{WSN} / \mathrm{TN}) \times 100
$$

\section{Extraction of protein and sample preparation for PAGE}

Protein degradation in the all Örgü cheeses was evaluated by electrophoresis as SDS-PAGE (12.5\% polyacrylamides gel) using the Leammli method (1970). Protein standards (SDS 7) were obtained from Sigma Chemical (St. Lous, MO) to identify degraded or breakdown products of protein molecules.

The completed electrophoresis gel was destined and preserved in the destining buffer solution. The developed gel pictures were used to quantify degradative products of casein fractions by an advanced computerized optical densitometer (OD) (UV transilluminator 2000, Bio Rad, Italy) located at the Laboratory of Research Centre in Suleyman Demirel University, Isparta-Turkey. The final numerical values of each breakdown product of protein molecules were quantitatively analyzed.

\section{Texture profile analysis (TPA)}

Texture profile Analysis has been practiced by cutting the curd in the shape of $4 \times 4 \times 4 \mathrm{~cm}$. In all recurrences, texture measurements have been practiced from eight different areas of product, which are selected randomly, as three parallels. In the room temperature, texture measurements have been practiced with Lloyd LF Plus Texture Analysis Gadget. In the analysis, $5 \mathrm{~mm}$ probe has been used and probe has been practiced with the force in the $1 \mathrm{~N}$ values. In the practiced analysis, the maximum load which probe has showed to pierce the samples has measured (Kaya, 2002).

\section{Mineral material and the determination of trace elements with ICP-OES}

$\mathrm{Ca}, \mathrm{Fe}, \mathrm{Mg}, \mathrm{Mn}, \mathrm{Cu}, \mathrm{Al}, \mathrm{Zn}$ content of Örgü Cheese has been determined. The samples were prepared as follows: approximately $1.0 \mathrm{~g}$ of sample, in the microwave system, has been lysed with $6 \mathrm{ml}$ $\mathrm{HNO}_{3}$ and $2 \mathrm{~mL} \mathrm{H}_{2} \mathrm{O}_{2}$. Temperature programme has been applied in $400 \mathrm{~W}$ two minutes, in $400 \mathrm{~W}$ two minutes in $400 \mathrm{~W}$ six minutes, in $400 \mathrm{~W}$ five minutes, in $800 \mathrm{~W}$ eight minutes. The last obtained solution has been diluted to $10 \mathrm{ml}$ with distilled water by cooling. The obtained solution has been analyzed with ICP-OES (Inductively Coupled Plasma Optical Emission Spectrometer; Perkin Elmer Inc. Optima 5300 DV; Massachusetts USA) (Bakırcıŏglu et al., 2011).

Aliquots of an ICP multielement standard solution (100 mg/L Merck) containing the analyzed elements was used in the preparation of calibration solutions. Working standard solutions were prepared by dilution of the stock standard solutions to desired concentration in $1 \% \mathrm{HNO}_{3}$. The ranges of the calibration curves ( 6 points) were selected to match the expected concentrations $(0-30 \mu \mathrm{g} / \mathrm{g})$ for all the elements of the sample studied by ICP-OES. The correlation coefficient $r^{2}$ obtained for all cases was 0.9999 .

\section{Scanning electron microscopy of Örgü cheeese}

Samples for scanning electron microscopy (SEM) were cut with a razon from the interior of the cheese and then diced into rectangular blocks approximately $5 \times 2 \times 2 \mathrm{~mm}$ these were immersed in a solution of $1 \%$ glutaraldehyde in $0.1 \mathrm{M}$ sodium cacodylate $(\mathrm{pH} \mathrm{7.2)}$ at room temperature for $1-2 \mathrm{~h}$ and then stored at $4{ }^{\circ} \mathrm{C}$. Groups of samples were subsequently washed in cacodylate buffer, dehydrated in a graded series of ethanol solutions, extracted with three changes of chloroform, transferred into ethanol, freeze-fractured in liquid nitrogen, thawed into ethanol, and finally dried at the critical point in carbon dioxide. The dried blocks were mounted on aluminium stubs, coated with a thin layer of gold in 
Table 1. The results of some parameters of Örgü cheese $(n=3)$

\begin{tabular}{|c|c|c|c|c|c|c|}
\hline \multirow{2}{*}{ Applied analysis } & \multicolumn{3}{|c|}{ 1. day } & \multicolumn{3}{|c|}{ 90. day } \\
\hline & A & B & $\mathrm{C}$ & $\mathrm{A}$ & B & $\mathrm{C}$ \\
\hline $\mathrm{pH}$ & $5.26 \pm 0.00^{\mathrm{cA}}$ & $5.24 \pm 0.02^{\mathrm{bA}}$ & $5.22 \pm 0.04^{\mathrm{bA}}$ & $5.78 \pm 0.16^{\mathrm{aA}}$ & $5.66 \pm 0.15^{\mathrm{aA}}$ & $5.48 \pm 0.01^{\mathrm{aA}}$ \\
\hline $\begin{array}{l}\text { Titratable acid } \\
\text { (\% LA) }\end{array}$ & $1.31 \pm 0.02^{\mathrm{aA}}$ & $1.36 \pm 0.02^{\mathrm{aA}}$ & $1.30 \pm 0.03^{\mathrm{aA}}$ & $1.06 \pm 0.00^{\mathrm{bcA}}$ & $1.02 \pm 0.05^{\mathrm{bA}}$ & $1.11 \pm 0.07^{\mathrm{bA}}$ \\
\hline Total nitrogen (\%) & $3.39 \pm 0.03^{\mathrm{aA}}$ & $3.51 \pm 0.00^{\mathrm{aA}}$ & $3.66 \pm 0.07^{\mathrm{aA}}$ & $3.37 \pm 0.01^{\mathrm{aA}}$ & $3.49 \pm 0.05^{\mathrm{abA}}$ & $3.43 \pm 0.03^{\mathrm{bA}}$ \\
\hline $\begin{array}{l}\text { Water-soluble } \\
\text { nitrogen }(\%)\end{array}$ & $0.42 \pm 0.02^{\mathrm{bA}}$ & $0.50 \pm 0.04^{\mathrm{bA}}$ & $0.47 \pm 0.03^{\mathrm{bA}}$ & $0.66 \pm 0.03^{\mathrm{aA}}$ & $0.67 \pm 0.04^{\mathrm{aA}}$ & $0.75 \pm 0.122^{\mathrm{aA}}$ \\
\hline Ripening index & $12.58 \pm 0.74^{\mathrm{bcA}}$ & $14.48 \pm 1.15^{\mathrm{bcA}}$ & $13.04 \pm 0.56^{\mathrm{bcA}}$ & $19.57 \pm 0.79^{\mathrm{aA}}$ & $19.23 \pm 1.49^{\mathrm{aA}}$ & $21.89 \pm 3.31^{\mathrm{aA}}$ \\
\hline Hardness (N) & $15.12 \pm 0.10^{\mathrm{aA}}$ & $15.94 \pm 0.92^{\mathrm{aA}}$ & $16.03 \pm 1.01^{\mathrm{aA}}$ & $14.58 \pm 1.96^{\mathrm{cA}}$ & $12.58 \pm 2.13^{\mathrm{cA}}$ & $13.03 \pm 0.23^{\mathrm{cA}}$ \\
\hline Dry-matter (\%) & $51.47 \pm 1.14^{\mathrm{aA}}$ & $49.45 \pm 0.53^{\mathrm{aA}}$ & $50.42 \pm 0.35^{\mathrm{aA}}$ & $46.06 \pm 2.15^{\mathrm{bA}}$ & $45.03 \pm 1.50^{\mathrm{bA}}$ & $44.52 \pm 1.44^{\mathrm{cA}}$ \\
\hline Fat (\%) & $18.50 \pm 0.00^{\mathrm{aA}}$ & $16.75 \pm 0.25^{\mathrm{abB}}$ & $16.25 \pm 0.25^{\mathrm{aB}}$ & $18.75 \pm 0.25^{\mathrm{aA}}$ & $17.12 \pm 0.12^{\mathrm{aB}}$ & $16.75 \pm 0.001^{\mathrm{aB}}$ \\
\hline Salt (\%) & $5.86 \pm 0.35^{\mathrm{dA}}$ & $6.28 \pm 0.29^{\mathrm{dA}}$ & $6.46 \pm 0.23^{\mathrm{dA}}$ & $8.25 \pm 0.11^{\mathrm{aA}}$ & $8.55 \pm 0.17^{\mathrm{aA}}$ & $8.31 \pm 0.53^{\mathrm{aA}}$ \\
\hline Ash (\%) & $7.18 \pm 0.47^{\mathrm{cA}}$ & $7.58 \pm 0.43^{\mathrm{cA}}$ & $7.30 \pm 0.13^{\mathrm{cA}}$ & $7.60 \pm 0.19^{\mathrm{cA}}$ & $8.07 \pm 0.03^{\mathrm{cA}}$ & $6.94 \pm 0.10^{\mathrm{cA}}$ \\
\hline Calcium (mg/g) & $5.19 \pm 0.23^{\mathrm{aA}}$ & $4.50 \pm 0.31^{\mathrm{aA}}$ & $4.39 \pm 0.54^{\mathrm{aA}}$ & $3.92 \pm 0.50^{\mathrm{bA}}$ & $3.51 \pm 0.28^{\mathrm{bA}}$ & $3.95 \pm 0.29^{\mathrm{bA}}$ \\
\hline Magnesium (mg/g) & $0.24 \pm 0.02^{2 \mathrm{~A}}$ & $0.20 \pm 0.04^{\mathrm{aA}}$ & $0.21 \pm 0.02^{2 \mathrm{~A}}$ & $0.17 \pm 0.02^{\mathrm{bA}}$ & $0.16 \pm 0.01^{\mathrm{bA}}$ & $0.16 \pm 0.01^{\mathrm{bA}}$ \\
\hline Zinc (mg/g) & $0.03 \pm 0.00^{\mathrm{aA}}$ & $0.03 \pm 0.00^{\mathrm{aAB}}$ & $0.03 \pm 0.00^{\mathrm{bB}}$ & $0.03 \pm 0.00^{\mathrm{aA}}$ & $0.03 \pm 0.00^{\mathrm{aA}}$ & $0.03 \pm 0.001^{\mathrm{aA}}$ \\
\hline Iron (mg/g) & $0.002 \pm 0.001^{\mathrm{abA}}$ & ${ }^{\mathrm{A}} 0.002 \pm 0.001^{\mathrm{abA}}$ & ${ }^{\mathrm{A}} 0.001 \pm 0.001^{\mathrm{abA}}$ & $0.002 \pm 0.001^{\mathrm{ab}}$ & ${ }^{\mathrm{A}} 0.002 \pm 0.001^{\mathrm{ab}}$ & ${ }^{\mathrm{A}} 0.001 \pm 0.001^{\mathrm{abA}}$ \\
\hline Copper (mg/g) & $0.003 \pm 0.002$ & $0.0005 \pm 0.001$ & $0.006 \pm 0.0003$ & ND & ND & ND \\
\hline Manganese (mg/g) & ND & ND & ND & ND & ND & ND \\
\hline
\end{tabular}

* difference between groups have determined that significant showed as capital letter. Difference between times have demonstrated that significant showed as small letter $(\mathrm{p}<0.01)$, A - calf rennet; $\mathrm{B}$ - recombinant chymosin; $\mathrm{C}$ - microbial enzyme; ND - not determined; $n$ - number of sample analyzed

a DSM-5 and examined by secondary electron imaging in a scanning electron microscope (Tunick et al., 2002).

\section{Statistical analyses}

Data were analysed by Statistica 7.0. The effect of heat treatment of cheese milk on the composition and same biochemical properties of Örgü cheese and the changes in studying parameters during ripening were investigated. Means with significant differences were compared by Tukey's multiple range tests (Winer et al., 1991).

\section{Results and discussion}

Analysis of raw milk

It has been found that raw milk which is used in the cheese production of $\mathrm{pH}$ value, titratable acidity, dry matter, fat and total nitrogen contents respectively; $6.63 \pm 0.01,0.154 \pm 0.010 \%, 11.431 \pm 0.394 \%$, $3.299 \pm 0.333 \%, 4.269 \pm 0.210 \%$. The dry matter $(\%)$, fat $(\%)$ and total nitrogen (\%) contents of raw milk which is used in cheese production are the same as Aydemir's (2000) findings.

\section{Chemical analyses of cheeses}

$\mathrm{pH}$ values of cheeses have shown (Table 1) an alteration between $5.22 \pm 0.04$ (first day, C sample) and $5.78 \pm 0.16\left(90^{\text {th }}\right.$ day A sample) during ripening 
time. Between samples of Örgü cheese, on the $90^{\text {th }}$ day, there was no significant difference. $\mathrm{pH}$ values of the cheeses which were produced with calf rennet was higher than the $\mathrm{pH}$ the other cheeses. Researchers have indicated differences in $\mathrm{pH}$ values of cheeses which are produced using different coagulating enzymes (Yun et al., 1993; Yaşar, 2007).

In the $90^{\text {th }}$ days of ripening, sample $B$ which was produced with recombinant chymosin gave the lowest value of lactic acid, while in $\mathrm{C}$ sample which is produced with microbial enzyme the highest value has been determined. Çelik and Turkoglu, (2007) demonstrated that acidity of Örgü cheese increased until the $60^{\text {th }}$ day of ripening period, while acidity decreased in the $90^{\text {th }}$ day.

When examining ratio of total nitrogen of Örgü cheeses it has been determined that the difference between ripening time is important but the difference between enzymes is not significant. In Aydemir's (2000) study, it was found total nitrogen ratio control group of kashar cheese in the first day as $3.747 \pm 0.053 \%$.

At the end of ripening, in C sample $(0.752 \pm 0.122$ $\%)$ water soluble nitrogen content has been observed in the highest level. In terms of ripening time, the statistical difference has been identified as important $(\mathrm{p}<0.01)$. Mutluer $(2007)$ has found the ratio of water soluble nitrogen between $0.730 \pm 0.096$ and $0.507 \pm 0.109$ Yun et al. (1993), have determined that the usage of recombinant chymosin, Cryphonectria parasitica protease and Rhizomucor miehei protease effect on the ratio of water-soluble nitrogen of cheeses in the mozzarella cheeses production.

The difference of values of ripening index in the storage period has been found as important statistically $(p<0.01)$. In the Kashar cheese which he produced by using calf rennet, recombinant chymosin, protease enzymes of Rhizomucor miehei, Yaşar (2007), has determined the highest ripening index in the Kashar cheese which is produced with recombinant chymosine. Also in our study, the lowest ripening index has been established. In B sample which is produced by using recombinant chymosin. The highest ripening index has been determined in C sample which is produced by using the protease of Rhizomucor miehei.

As from the first day of ripening to the $90^{\text {th }}$ in the dry-matter values decrease have been seen. In the first day, B sample which is produced with recombinant chymosin has the lowest dry-matter value, in the $90^{\text {th }}$ day. The highest dry-matter value has been found in the A sample which is produced with calf rennet. The dry-matter values of cheeses has demonstrated similar values of the other researchers findings (Çelik and Türkoğlu, 2007; Türkoğlu et al., 2003).

At the end of the ripening although A sample which is produced with calf rennet has the highest fat ratio $(18.75 \pm 0.250 \%)$, it has been determined that C sample which is produced with Rhizomucor miehei protease $(16.250 \pm 0.001 \%)$ has the lowest fat ratio. $\mathrm{B}$ and $\mathrm{C}$ cheese samples demonstrated statistically similar values. The values which were found were atoned to the values which were given by Koçak et al. (1998).

In the cheeses salt ratios have shown regular increase during ripening. As cheese sample (A sample) which is produced with calf rennet has the lowest salt ratio, it has been notified that cheese sample (C sample) which is produced with microbial enzyme (Rhizomucor miehei protease), has the highest salt ratio. It has been reported that the usage of different coagulating enzyme has not an effect on the salt ratio (Yaar, 2007; Johnston et al., 1994).

Although the differences which are seen between times in the ripening period, have been found as significant $(\mathrm{p}<0.01)$, between $6.947 \pm 0.102 \%$ - $8.076 \pm 0.033 \%$ (Table 1) values of ash ratio of cheese samples have similar values in the $90^{\text {th }}$ day. Çelik and Türkoğlu (2007), have found the ratio of ash between $7.09 \pm 0.04 \%$ and $8.22 \pm 0.04 \%$ values in the cheese which is produced with raw milk.

In the first day of ripening, the hardness of Örgü cheese has been found between 15.128 \pm 0.105 Newton $(\mathrm{N})$ and $16.036 \pm 1.014 \mathrm{~N}$ values. Kaya (2002), has determined that the hardness of cheeses which ripened in the brines which have $5 \%$ salt concentration is $3.45 \mathrm{~N}$, the hardness of cheeses which are ripened in the brines which have $15 \%$ salt concentration is $10.75 \mathrm{~N}$, the hardness of cheeses which are stored in the brine which has $25 \%$ salt concentration is $38.36 \mathrm{~N}$.

\section{Mineral material contents of cheeses}

It has been found that the lowest calcium quantity $3.518 \mathrm{mg} / \mathrm{g}$ is seen in Örgü cheese (A) which 
is gained from Aspergillus niger spp. awamori with recombinant chymosin, the highest quantity 3.959 $\mathrm{mg} / \mathrm{g}$ is seen in the Örgü cheese which is produced with Rhizomucor miehei protease. It has been observed that amount of calcium decrease during ripening period in brine. Tejada et al. (2008), Murcia al Vino has found the value of Ca quantity between $1123 \mathrm{mg} / 100 \mathrm{~g}$ and $895 \mathrm{mg} / 100 \mathrm{~g}$ in the goat cheese which is produced with animal rennet. The values which we found in the Örgü cheese are low a little in comparison to Tejada et al. (2008), findings. It has been thought that its reason can be derived from the differences in the cheese production process.

The changes of the magnesia contents of cheese samples in the storage period has been found as important statistically $(\mathrm{p}<0.01)$. But, difference between cheese groups has not been determined ( $p>0.01)$. Cichoscki et al. (2002), have examined mineral contents in semi-hard Prato cheese. They have designated the quantity of magnesia values between $0.50 \pm 0.04 \mathrm{mg} / \mathrm{g}$ and $0.55 \pm 0.09 \mathrm{mg} / \mathrm{g}$, but magnesia values in Örgü cheeses are lower than that study.

The amounts of zinc of the cheeses have been determined between $0.028 \pm 0.001 \mathrm{mg} / \mathrm{g}$ (cheese sample which is produced with recombinant enzyme) and $0.035 \pm 0.001 \mathrm{mg} / \mathrm{g}$ (with microbial enzyme). Sanjuán et al. (1998), have examined mineral material contents of Los Pedroches cheeses. They have determined zinc quantities of cheeses which are produced with animal rennet as being between $2909 \mu \mathrm{g} / 100 \mathrm{~g}$ and $3800 \mu \mathrm{g} / 100 \mathrm{~g}$ values.

At the end of the storage the highest values of iron amounts of cheeses have been notified as $0.002 \pm 0.001 \mathrm{mg} / \mathrm{g}$. Mendil (2006), has found the iron quantity in the Kars kashar cheese obtained from market $7.5 \mu \mathrm{g} / \mathrm{g}$.

While copper in the samples in the beginning of storage is found, it has not been found once more during storage periods. Bontinis et al. (2008), have found copper quantity in Xinotyri cheese which is a traditional Greek cheese between $1.19 \mathrm{mg} / \mathrm{kg}$ and $1.59 \mathrm{mg} / \mathrm{kg}$ values during the storage period.

Merdivan et al. (2004), have informed that the lowest quantity in cheeses belongs to magnanese values between cheese groups which they examined comparing to other minerals. They have not encountered manganese in a lot of cheese sample. In our study it has not run across manganese in the samples.

Table 2. Caseine ratios have determined that Örgü cheeses produced with different coagulant enzyme in ripening periods $(\%)(n=3)$

\begin{tabular}{|c|c|c|c|c|c|}
\hline \multirow{2}{*}{ *Sample } & \multirow{2}{*}{ Caseines (\%) } & \multicolumn{4}{|c|}{ Ripening times (day) } \\
\hline & & 1 & 30 & 60 & 90 \\
\hline \multirow{3}{*}{ A } & $\alpha$-caseine & $35.405 \pm 0.385^{\mathrm{aA}}$ & $34.095 \pm 0.585^{\mathrm{aA}}$ & $32.420 \pm 0.150^{\mathrm{aB}}$ & $28.315 \pm 0.035^{\mathrm{aC}}$ \\
\hline & $\beta$-caseine & $33.820 \pm 0.460^{\mathrm{aA}}$ & $30.935 \pm 0.665^{\mathrm{aB}}$ & $31.450 \pm 0.120^{\mathrm{aBC}}$ & $27.620 \pm 0.300^{\mathrm{aC}}$ \\
\hline & $\gamma$-caseine and peptids & $30.775 \pm 0.075^{\mathrm{aA}}$ & $34.970 \pm 0.080^{\mathrm{aB}}$ & $36.130 \pm 0.270^{\mathrm{aC}}$ & $44.065 \pm 0.335^{\mathrm{aD}}$ \\
\hline \multirow{3}{*}{ B } & $\alpha$-caseine & $34.060 \pm 0.810^{\mathrm{aA}}$ & $32.000 \pm 1.720^{\mathrm{aA}}$ & $30.285 \pm 0.135^{\mathrm{aB}}$ & $28.715 \pm 0.795^{\mathrm{aC}}$ \\
\hline & $\beta$-caseine & $34.995 \pm 0.425^{\mathrm{aA}}$ & $33.710 \pm 1.160^{\mathrm{aB}}$ & $30.200 \pm 0.550^{\mathrm{aBC}}$ & $29.285 \pm 1.865^{\mathrm{aC}}$ \\
\hline & $\gamma$-caseine and peptids & $30.945 \pm 1.235^{\mathrm{aA}}$ & $34.290 \pm 2.880^{\mathrm{aB}}$ & $39.515 \pm 0.415^{\mathrm{aC}}$ & $42.000 \pm 1.070^{\mathrm{aD}}$ \\
\hline \multirow{3}{*}{$\mathrm{C}$} & $\alpha$-caseine & $35.565 \pm 0.155^{\mathrm{aA}}$ & $33.120 \pm 0.630^{\mathrm{aA}}$ & $30.660 \pm 0.050^{\mathrm{aB}}$ & $28.475 \pm 1.095^{\mathrm{aC}}$ \\
\hline & $\beta$-caseine & $34.540 \pm 0.040^{\mathrm{aA}}$ & $31.475 \pm 1.205^{\mathrm{aB}}$ & $29.815 \pm 0.105^{\mathrm{aBC}}$ & $29.450 \pm 0.180^{\mathrm{aC}}$ \\
\hline & $\gamma$-caseine and peptids & $29.895 \pm 0.195^{\mathrm{aA}}$ & $35.405 \pm 1.835^{\mathrm{aB}}$ & $39.525 \pm 0.155^{\mathrm{aC}}$ & $42.075 \pm 0.915^{\mathrm{aD}}$ \\
\hline
\end{tabular}

* difference between groups have determined that significant showed as capital letter. Difference between times have demonstrated that significant showed as small $(\mathrm{p}<0.01)$, A - calf rennet; B - recombinant chymosin; C - microbial enzyme; $\mathrm{n}$ - number of sample analyzed 

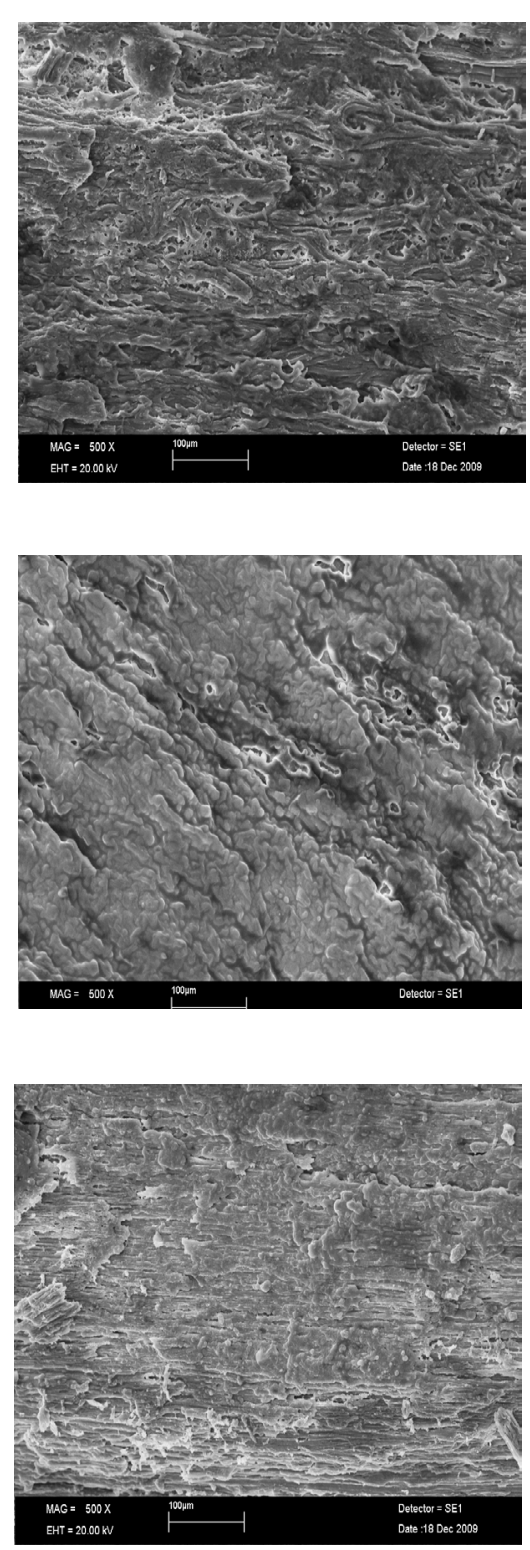

Figure 2. Scanning electron micrographs of the sample cheese (A) Renna (B) Renmax (C) Mayasan

\section{SDS-PAGE findings of cheeses}

$\alpha$-casein quantity of cheeses have been determined $35.565 \pm 0.155 \%$ and $34.060 \pm 0.810 \%$ levels in the first day of ripening. $\alpha$-casein quantity has been demonstrated between $28.315 \pm 0.035 \%$ (A Sample) and 28.715 $\pm 0.795 \%$ (B sample) levels in the $90^{\text {th }}$ day of ripening. $\beta$-casein quantities of cheeses are between 33.820 $0.460 \%$ (A Sample) and $34.995 \pm 0.425 \%$ (B sample) (Table 2) levels in the first day of ripening. As to the end of ripening they have been found between $27.620 \pm 0.300 \%$ (A sample) and 29.450 $0.180 \%$ (C sample) levels.

Yaşar (2007), reported that the lowest $\alpha$-casein ratio at the end of ripening was observed when the Kashar cheeses was produced with calf rennet, while the highest $\alpha$-casein ratio was observed when the cheese was produced with microbial enzyme.

\section{SEM findings}

Microstructure studies provide strategic information to understand and to control cheese properties. Representative scanning electron micrographs of the sample cheese at 500x magnifications are presented in Figure 2.

In all sample cheeses, the microstructure is characterized by networks of parallel-oriented protein fibres occupied by serum and fat droplets. But, the protein matrix of B sample was more uniform than the others. This is in agreement with the findings of Lobato-Calleros et al. (2007), Dinkçi et al. (2011), Kindstedt and Guo (1997).

\section{Conclusion}

The use of three enzymes (calf rennet, microbial enzymes, and recombinant chymosin) in the coagulation of milk for production of Örgü cheese demonstrated to have similar characteristics regarding $\mathrm{pH}$, titratable acidity, total nitrogen, ripening index, hardness, mineral materials and casein ratios of the cheese.

\section{Učinak različitih koagulirajućih enzima na kvalitetu tradicionalnog Örgü sira (pleteni sir)}

\section{Sažetak}

Örgü sir je proizveden korištenjem nekoliko različitih enzima (teleće sirilo, mikrobni enzim, rekombinantni himozin) te je praćen utjecaj različitih enzima zgrušavanja na osobine mineralnih tvari i sira tijekom 90 dana zrenja. Sadržaj mineralnih tvari Örgü sira utvrđen je ICP-OES (induktivno atomska 
emisijska spektroskopija). Stupanj proteolize sira utvrđen je kemijskom analizom pomoću SDS-PAGE (sodijum dodecil sulfat poliakrilamid gel elektroforeza). Utvrđene razlike između rezultata, titracijske kiselosti, ukupnog dušika, dušika topivog u vodi, indeksa zrenja, ukupne suhe tvari, masti, masti u suhoj tvari, soli, soli u suhoj tvari, pepela, teksture, mineralnih tvari (Ca, Fe, $\mathrm{Cu}, \mathrm{Al}, \mathrm{Mg}, \mathrm{Mn})$ u Örgü siru nisu statistički značajne. Svaki od korištenih enzima ima sličan utjecaj na $\alpha$-kazein i $\beta$-kazein tijekom dozrijevanja te su svi izračunati omjeri bili vrlo slični.

\section{Ključne riječi: Örgü sir, koagulirajući enzimi, mineralne tvari, mikrostruktura}

\section{References}

1. Ahmed, M.A.I., Morishima, I., Babiker, E.E., Mori, N. (2009): Characterisation of partially purified milk-clotting enzyme from solanum dubium fresen seeds, Food Chemistry 116, 395-400. doi: dx.doi.org/10.1016/j.foodchem.2008.11.072

2. Alichanidis, E., Anifantakis, E.M., Polychroniadou, A., Nanou, M. (1984): Suitability of some microbial coagulants for feta cheese manufacture, Journal of Dairy Research 51, 141-147. doi: dx.doi.org/10.1017/S0022029900023402

3. AOAC (2000a) Official Methods of Analysis of the Association of Official Chemists. Acidity of Milk AOAC Official Method 947.05, Chapter 33, 17th ed., 7, USA, 2000a.

4. AOAC (2000b) Official Methods of Analysis of the Association of Official Chemists. Solids in Milk AOAC Official Method 990.20, Chapter 33, $17^{\text {th }}$ ed., 33, USA, 2000b.

5. AOAC (2000c) Official Methods of Analysis of the Association of Official Chemists. Solids in Cheese, AOAC Official Method 926.08, Chapter 33, $17^{\text {th }}$ ed., 70, USA, 2000c

6. Aydemir, A.S. (2000): Lipaz Enziminin (Lipase $\left.{ }^{\circledast}\right)$ Beyaz ve Kaşar Peynirlerinin Olgunlaşması Üzerine Etkisi, Ankara Üniversitesi Fen Bilimleri Enstitüsü, Doktora Tezi, 350s, Ankara.

7. Bakırcıoğlu, D., Bakırcıoğlu-Kurtuluş, Y., Ucar, G. (2011): Determination of some traces metal levels in cheese samples packaged in plastic and tin containers by ICP-OES after dry, wet and microwawe digestion, Food and Chemical Toxicology 49, 202-207. doi: dx.doi.org/10.1016/j.fct.2010.10.017

8. Bontinis, T.G., Mallatou, H., Alichanidis, E., Kakouri, A., Samelis, J. (2008): Physicochemical, microbiological and sensory changes during ripening and storage of xinotyri, a traditional greek cheese from raw goat's milk, International Journal of Dairy Technology 61 (3), 231-236. doi: dx.doi.org/10.1111/j.1471-0307.2008.00404.x
9. Cichoscki, A.J., Valduga, E., Valduga, A.T., Tornadijo, M.E., Fresno, J.M. (2002): Characterization of prato cheese, a Brazilian semi-hard cow variety: evolution of physico-chemical parameters and mineral composition during ripening, Food Control 13, 329-336. doi: dx.doi.org/10.1016/S0956-7135(02)00039-7

10. Çelik, Ş., Türkoğlu, H. (2007): Ripening of traditional Örgü cheese manufactured with raw or pasteurized milk: composition and biochemical properties, International Journal of Dairy Technology 60 (4), 253-258. doi: dx.doi.org/10.1111/j.1471-0307.2007.00344.x

11. Dinkçi, N., Kesenkaş, H., Seçkin, A.K., Kınık, Ö., Gönç, S. (2011): Influence of a vegetable fat blend on the texture, microstructure and sensory properties of kashar cheese, Grasas y aceties 62 (3), 275-283.

12. Er, B., Sarımehmetoğlu, B. (2009): Süt endüstrisinde mikrobiyel enzim kullanımı, Veteriner Hekim Derneği Dergisi 80 (1), 25-30.

13. Gripon, J.C., Desmazeaud, M.J., Le Bars, D., Bergere, J.L. (1975): Etude du rôle des microorganismes et des enzymes au cours de la maturation des fromages, Le Lait 548, 502-516. doi: dx.doi.org/10.1051/lait:197554828

14. Hayaloğlu, A.A., Özer, B.H., Fox, P.F. (2008): Cheeses of Turkey: 2. varieties ripened under brine, Dairy Science Technology 88, 225-244. doi: dx.doi.org/10.1051/dst:2007014

15. Henriksen, C.M., Nilsson, D., Hansen, S., Johansen, E. (1999): Industrial Applications of Genetically Modified Microorganisms: Gene Technology at Chr. Hansen A/S, International Dairy Journal 9, 17-23. doi: dx.doi.org/10.1016/S0958-6946(99)00040-0

16. Johnston, K.A., Dunlop, F.P., Coker, C.J., Wards, S.M. (1994): Comparisons between the electrophoretic pattern and textural assessment of aged Cheddar Cheese made using various levels of calf rennet or microbial coagulant (Rennilase 46 L). Dairy Science Abstract 56 (4), 2266.

17. James C.S. (1999): Analytical Chemistry of Foods. Oxford: Chapman \& Hall, 178, London. ISBN 0834212986.

18. Kaya, S. (2002): Effect of salt on hardness and Whiteness of Gaziantep Cheese during short-term brining, Journal of Food Engineering 52, 155-159. doi: dx.doi.org/10.1016/S0260-8774(01)00098-X

19. Kindstedt P.S., Guo, M.R. (1997): Resent developments in the science and technology of pizza cheese, The Aust. Journal Dairy Technology 52, 41-43.

20. Koçak, C., Erşen, N., Aydınoğlu, G., Uslu, K. (1998): Ankara piyasinda satılan kaşar peynirlerinin proteoliz düzeyi üzerinde bir araştırma, Gıda Teknojisi Dergisi 23 (4), 247-251.

21. Laemmli, U.K. (1970): Cleavage of structural proteins during the assembly of the head of bacteriophage T4, Nature 227, 680-685. doi: dx.doi.org/10.1038/227680a0

22. Lobato-Calleros, C., Vermon-Carter, E.J. (1998): Microstructure and texture of cheese analogs containing different types of fat, Journal of Texture Studies 29, 569-586. doi: dx.doi.org/10.1111/j.1745-4603.1998.tb00184.x 
23. Mendil, D. (2006): Mineral and Trace Metal Levels in Some Cheese Collected from Turkey, Food Chemistry 96, 532-537. doi: dx.doi.org/10.1016/j.foodchem.2005.03.006

24. Merdivan, M., Yilmaz, E., Hamamc1, C., Aygun, R.S. (2004): Basic nutrients and element contents of white cheese of Diyarbakır in Turkey, Food Chemistry 87, 163-171. doi: dx.doi.org/10.1016/j.foodchem.2003.11.002

25. Mutluer, U. (2007): Uygulanan Bazı Farklı İşlemlerin Sünme Peynirinin Özellikleri Üzerine Etkisi, Gıda Mühendisliği Ana Bilim Dalı, Yüksek Lisans Tezi, 64s, Adana.

26. Sanjuán E., Saavedra, P., Millán, R., Castelo, M. (1998): Effect of ripening and type of rennet on the mineral content of Los Pedroches Cheese, Journal of Food Quality 21, 187-200. doi: dx.doi.org/10.1111/j.1745-4557.1998.tb00515.x

27. Shieh, C., Thi, L.P., Shih, I. (2009): Milk-clotting enzymes produced by culture of Bacillus subtilis natto, Biochemical Engineering Journal 43, 85-91. doi: dx.doi.org/10.1016/j.bej.2008.09.003

28. Tejada, L., Abellán, A., Prados, F., Cayuela, J.M. (2008): Compositional characteristics of Murcia al Vino Goat's Cheese made with calf rennet and plant coagulant, International Journal of Dairy Technology 61 (2), 119-125. doi: dx.doi.org/10.1111/j.1471-0307.2008.00396.x
29. Tunick, M.H., Van Hekken, D.L., Cooke, P.H., Malin, E.L. (2002):Transmission Electron Microscopy of Mozzarella Cheeses Made from Microfluidized Milk, Journal Agricultural and Food Chemistry 50, 99-103. doi: dx.doi.org/10.1021/jf010633c

30. Türkoğlu, H., Ceylan, Z.G., Dayısoylu, K.S. (2003): The microbiological and chemical quality of Örgü Cheese produced in Turkey, Pakistan Journal of Nutrition 2 (2), 92-94. doi: dx.doi.org/10.3923/pjn.2003.92.94

31. Ustunol, Z., Hicks, C.L. (1990): Effect of milk-clotting enzymes on cheese yield, Journal of Dairy Science 73, 8-16. doi: dx.doi.org/10.3168/jds.S0022-0302(90) 78639-0

32. Yaşar, K., (2007): Farklı Pıhtılaştırıcı Enzim Kullanımının ve Olgunlaşma Süresinin Kaşar Peynirinin Özellikleri Üzerine Etkisi, Gıda Mühendisliği Anabilim Dalı, Doktora Tezi, 134s, Adana.

33. Yun, J.J., Kiely, L.J., Kındstedt, P.S., Barbano, D.M. (1993): Mozzarella Cheese: impact of coagulant type on functional properties, Journal of Dairy Science 76, 3657-3663. doi: dx.doi.org/10.3168/jds.S0022-0302(93)77708-5

34. Winer, B.J., Brown, D.R., Michels, K.M. (1991): Statistical principles in experimental design, Third Edition. Boston, Massachusetts Burr Ridge. Illinois. ISBN 0-07070982-3, p.1057. 